\title{
Trastuzumab Emtansine
}

National Cancer Institute

\section{Source}

National Cancer Institute. Trastuzumab Emtansine. NCI Thesaurus. Code C82492.

An antibody-drug conjug ate (ADC) consisting of the recombinant anti-epidermal growth factor receptor 2 (HER2) monoclonal antibody trastuzumab conjug ated to the maytansinoid DM1 via a nonreducible thioether linkage (MCC) with potential antineoplastic activity. The trastuzumab moiety of this ADC binds to HER2 on tumor cell surfaces; upon internalization, the DM1 moiety is released and binds to tubulin, thereby disrupting microtubule assembly/disassembly dynamics and inhibiting cell division and the proliferation of cancer cells that overexpress HER2. Linkage of antibody and drug through a nonreducible linker has been reported to contribute to the improved efficacy and reduced toxicity of this ADC compared to similar ADCs constructed with reducible linkers. 